\title{
Technological universities and the diversification of higher education from the perspective of university rankings
}

\author{
Caroline Lievore ${ }^{1}$ \\ Orcid: https://orcid.org/0000-0003-2448-089X \\ Renata Klafke ${ }^{2}$ \\ Orcid: https://orcid.org/0000-0002-0241-988X \\ Luiz Alberto Pilatti ${ }^{3}$ \\ Orcid: https://orcid.org/0000-0003-2679-9191
}

\begin{abstract}
This work is about Technological Universities (TUs) and about the diversification in the higher education system from the perspective of university rankings. The objective, in addition to bringing some reflections on the social, economic and technological importance of TUs, is to consider the way in which global university rankings impact TUs and the diversification of the Higher Education System. Many TUs are left out of the group called World Class University (WCU) because the evaluations neglect indicators related to entrepreneurial activities and technology transfer and innovation, which are fundamental for economic development by modifying indicators such as HDI, Per capita income or Unemployment rates Keywords: Technological Universities; University Rankings; Economic Development.
\end{abstract}

\section{Resumo}

Este trabalho trata das Universidades Tecnológicas (UTs) e da diversificação do sistema de ensino superior na perspectiva dos rankings universitários. O objetivo, além de trazer algumas reflexões sobre a importância social, econômica e tecnológica das TUs, é refletir em relação à forma como os rankings universitários globais impactam as TUs e a diversificação do Sistema de Ensino Superior. Muitas TUs ficam de fora do grupo denominado World Class University (WCU), porque as avaliações negligenciam indicadores relacionados às atividades empreendedoras e de transferência de tecnologia e inovação, sendo fundamentais para o desenvolvimento econômico. Eles modificam indicadores como IDH, renda per capita ou taxas de desemprego.

Palavras-chave: Universidades Tecnológicas; Ranking das Universidades; Desenvolvimento Econômico.

\footnotetext{
${ }^{1} \mathrm{PhD}$ in Teaching of Science and Technology by the Federal Technological University of Paraná (UTFPR); Ponta Grossa, Paraná, Brazil; E-mail: carolievore1@gmail.com

${ }^{2}$ PhD in Business Management (2021) and Master Degree in Production Engineering (2016). Professor at instituto Federal do Rio Grande do Sul (IFRS). Nena.klafke@gmail.com

${ }^{3}$ Doctor in Education from the State University of Campinas (UNICAMP). Full Professor at the Federal Technological University of Paraná (UTFPR); Ponta Grossa, Paraná, Brazil. It is linked to the Graduate Programs in Production Engineering (PPGEP) and Teaching of Science and Technology (PPGECT) in UTFPR. Research Productivity Scholar - CNPq. E-mail: lapilatti@utfpr.edu.br
} 


\section{Introduction}

Technological Universities (TUs) emerged in 18th century Europe, considered the birthplace of technological education (PILATTI; LIEVORE, 2018), and spread during the 20th Century Technological Revolution to other countries (COUTINHO, 1992; PILATTI; LIEVORE, 2018). Its creation was due to the social and technological changes that were occurring (CASTELLS, 2005) and the need for qualified labour (PILATTI; LIEVORE, 2018; HASANEFENDIC, 2018). Education closer to the labour market and the democratization of higher education in regions where it was concentrated in large centers was necessary (HASANEFENDIC, 2018). In Europe, several countries have joined the binary system of higher education composed of (classical) and specialized universities, the Technological Universities or Universities of Applied Sciences.

In addition to the strong relationship with the market, another distinguishing factor of TUs is the way of conducting Teaching, which is the first university mission (MOLASGALLART et al. 2002; HSU, 2015) without renouncing Research, the second university mission (MOLAS-GALLART et al. 2002; HSU, 2015). The shorter training courses and market orientation are also characteristic of Education in TUs (HASANEFENDIC, 2018), determined by the speed of technological transformations and radical changes in the skills systems demanded by the productive sector (WORLD ECONOMIC FORUM, 2018). Research in TUs is also distinct, tending to focus on applicability (HASANEFENDIC, 2018). These differences are part of a continuum and are very difficult to establish (HELMANN, 2019).

However, the biggest differential of TUs is found in the third university mission, which resides in the Transfer of Technology (TT) to society (MOLAS-GALLART, et al. 2002; HSU, 2015; RIBEIRO-SORIANO; BERBEGAL-MIRABENT，2017; PEREZ-ESPARRELLS; ORDUNA-MALEA, 2018) based on innovation and innovation environments (Audy, 2017). Among the activities involving the third mission are: the exploration and application of knowledge and technologies outside the academic environment, linked to the resolution of problems in the productive sector (MONTESINOS et al. 2008; PIIRAINEN et al. 2016) entrepreneurial and job creation activities start-ups (MONTESINOS et al. 2008; PEREZESPARRELLS; ORDUNA-MALEA, 2018) enabling the development and improvement in the quality of corporate life. In TUs, the third mission is understood mainly in terms of innovation and technology transfer policies from the university to industry (PIIRAINEN et al. 2016) with a concentration more on the market-pull model and less on the science-push model (PILATTI; LIEVORE, 2018).

Inserted in a scenario of constant transformations, universities, both classical (CU) and technological (TU), can change their models if they are conducted by an evaluative or evaluative system that establishes another direction (MORRIS, 2011; ALTBACH; HAZELKORN, 2017). It is known that some countries have changed their financing policies for universities (LI, 2012) with a focus on the development of called "global universities" (DOĞAN; AL, 2019). This has occurred since the launch, in 2003, of the Academic Ranking of World Universities (ARWU), created to compare Chinese universities with those of the rest of the world (DOGAN; AL, 2019), initiating a process of competition between universities (MOHRMAN, 2014; MARGINSON, 2017). After this, other rankings emerged, such as Times Higher Education (THE), UniRank University Ranking and Quacquarelli Symonds World University Ranking (QS).

Global rankings influence and affect Higher Education Institutions (HEI), as well as political, public and investor opinion (HAZELKORN et al. 2014, MARGISON, 2017; ALTBACH; HAZELKORN, 2017). The better the positioning of universities in the rankings, the greater the visibility of institutions (ALTBACH; HAZELKORN, 2017), the greater the 
public and private funding (MARGINSON, 2017), in addition to guaranteeing the status of WCU (CHENG et al. 2014).

WCU are recognized as global universities of intensive research and of great importance for the social and economic development of nations (SALMI, 2009; CHENG et al. 2014), given their leadership in criteria such as international research and cited works (HUISMAN, 2008, CHENG et al. 2014), are characterized by the high availability of researchers who are references in their fields; the ability to drive innovative ideas; ability to recruit and retain teaching and student staff and efficiency in attracting financial resources and donations (Salmi, 2009). However, when it comes to global rankings, the definition of WCU could be expanded, considering not only excellence in teaching and research, but also in the third mission with indicators related to social, entrepreneurial and innovation activities (MONTESINOS et al. 2008).

\section{Reflection}

Como parte do processo de submissão, os autores são obrigados a verificar a conformidade da submissão em relação a todos os itens listados a seguir. As submissões que não estiverem de acordo com as normas serão devolvidas aos autores.

Considering that the criteria and indicators used by global university rankings are the same for all HEI and considering that an important portion of institutions aspire to high positions in rankings, we can infer that, with the prioritization of what is valued in rankings, in the medium term in response to this scenario, the diversification of the higher education system, which differentiates CUs and TUs, will be less and less.

As they are evaluated by a certain standard, the tendency is for there to be greater homogeneity in university missions.

Why is it important to diversify higher education?

The need for diversification of higher education is strongly based on the fact that, when education was directed only to the elite (CUNHA, 1988; SGUISSARDI, 2006; TROW, 2007; SILVEIRA; BIANCHETTI, 2016), in reality it was actually a single education, but, as access expanded, there was a need to diversify the education system (HASANEFENDIC, 2018; HELMANN, 2019), through the method and production of knowledge oriented to the professional field (Hasanefendic, 2018) and fundamentally, to help individuals and communities to develop in different ways (HAZELKORN et al. 2014). For Taylor (2003), diversity in higher education implies a set of powerful social and political values that involve social inclusion, anti-elitism, the ability to respond to new audiences and increase the students' choice.

Evidently, the diversification of the education system, in global terms, could be accompanied by a process of diversification of research and the university's relationship with the market. In order to have a binary system, with institutions betting on different things, diversified forms of assessment are needed, in environments that are highly competitive. However, more important than differentiating, is to realize that the future is not only in research, today prioritized by the rankings. The immediate future lies in the specialization of professions, short and quality training, postgraduate training, and an entrepreneurial and innovative culture. Although these elements are contained in the different university missions, they are not in proportion to their relevance, in the rankings.

Because they are largely more traditional, CUs tend to have greater inertia for this type of "offer", that is, less flexibility to meet shorter, more technical training courses for adults and entrepreneurs. However, even these institutions have been evolving, including in these aspects. 

system?

What is the impact of rankings on TUs and on the diversification of the higher education

With a growing interest from universities for being in the best positions of the most important rankings, the tendency is for more homogeneity to occur in university missions. If we think about the diversification of higher education, this may cause changes in institutional strategies and, with these changes, especially TUs may significantly change their purposes. Altbach and Hazelkorn (2017) ratify that many universities stop focusing on their mission, to focus on global classifications.

The rankings neglect important indicators for universities with a more specialized, technical and business profile such as TUs, such as: (1) number of start-ups and spinoffs created, (2) patents, (3) technology licensing and (4) research by contract (MONTESINOS et al. 2008; PEREZ-ESPARRELLS; ORDUNA-MALEA, 2018). The evaluation of these indicators can also be supported by the social relevance that these elements represent. In concrete reality, there is a possible departure from the characteristics that make up a TU in order to adapt to the metrics established by the rankings.

Should the system be diversified? If so, should TUs exist?

National policy makers should ask themselves whether and how many WCU are desirable and affordable with public sector investment. Second, to inquire about the need to separate university denominations, as TUs have, and to promote different types of institutions in the concrete reality. With these responses, the bodies responsible for the rankings could consider three points. First, the specialist character of the TUs, which could more rigorously assume the responsibilities, linked to the third mission, given its interface between the academic and business worlds. Second, the social relevance that metrics based on the third mission represent for the social and economic development of the territories. The third is almost a reflection. Are WCU "just" research universities? If the answer is no, the evaluation criteria should be expanded.

It is noteworthy that many governments still argue that there is no way to carry out a competitive investigation in all higher education institutions and refer to the Californian higher education system. In this extremely selective system, only a group of universities develops research, the University of California which has Berkeley and Los Angeles as a reference. The rest, California State University (CSU) do very little research and the California Community Colleges (CCC) do not conduct research and do not have doctors on their staff (HELMANN, 2019). However, a study by Harkavy (2006) shows why American higher education, today shaped by an elitist and idealistic theory, has failed to carry out its democratic mission and the impacts of this system in the USA.

TUs are more directed towards entrepreneurship; spin-off, fostering start-ups and technology licensing (RUTyP, 2018), impacting job creation and serving as engines of social and economic development in the regions where they operate (ALVES et al. 2015; HASANEFENDIC, 2018; HELMANN, 2019). The generation of jobs is increasingly important for the development of a society (WORLD ECONOMIC FORUM, 2018). And, as a result of countless economic pressures, companies are challenged to continually improve their productivity, resulting in an increase in sales (due to technological advances), but, on the other hand, leads to a reduction in the number of jobs. On the other hand, the academy does not have the function of creating jobs, but of training people capable of creating jobs. That said, the relationships between education, job creation and economic development are very complex relationships that TUs have already understood. 
We envision a redirection. The rankings, which guide the future of universities, need to understand the process more broadly. Such a reading will perhaps produce a fourth university mission aimed at the need to create jobs and share the risks of creating jobs. This is an extremely critical issue, but one that needs to be considered. Some TUs are already working in this direction, as are the cases of Technical University Munich (TUM), Massachusetts Institute of Technology (MIT) and Eidgenössische Technische Hochschule Zurich (ETHZ).

The rankings need to go far beyond the universities second mission.

\section{References}

ALTBACH, Philip G.; HAZELKORN, Ellen. Pursuing rankings in the age of massification: For most—forget about it. International Higher Education, n. 89, p. 8-10, 2017.

ALVES, João; CARVALHO, L., CARVALHO, R., CORREIA, F., CUNHA, J., FLOUR, L., FERNANDES, J., FERREIRA, M., LUCAS, E., MOURATO, J. \& NICOLAU, A. The impact of polytechnic institutes on the local economy. Tertiary Education and Management, v. 21, n. 2, p. 81-98, 2015.

CASTELLS, Manuel. The rise of the network society. John Wiley \& sons, 2011.

CHENG, Ying; WANG, Qi; LIU, Nian Cai. How world-class universities affect global higher education. In: How world-class universities affect global higher education. Sense Publishers, Rotterdam, 2014. p. 1-10.

DOĞAN, Güleda; AL, Umut. Is it possible to rank universities using fewer indicators? A study on five international university rankings. Aslib journal of information management, 2019.

HARKAVY, Ira. The role of universities in advancing citizenship and social justice in the $21 \mathrm{st}$ century. Education, citizenship and social justice, v. 1, n. 1, p. 5-37, 2006.

HASANEFENDIC, Sandra. Responding to new policy demands: A comparative study of Portuguese and Dutch non-university higher education organizations. 2018. 231f. Thesis (School of Sociology and Public Policy) Department of Political Science and Public Policy. Lisbon University Institute, Lisbon, 2018.

HAZELKORN, Ellen; LOUKKOLA, Tia; ZHANG, Thérèse. Rankings in Institutional Strategies and Processes: Impact or Illusion? European University Association. Avenue de l'Yser, 24, 1040 Brussels, Belgium, 2014.

HELMANN, C. Lievore. Federal Technological University of Paraná and Polytechnic Institute of Bragança: a comparative study. 2019. 428f. Thesis (Federal Technological University of Paraná), Graduate Program in Science and Technology Teaching, Ponta Grossa, Brazil, 2019.

HAZELKORN, Ellen. Rankings and the reshaping of higher education: The battle for world-class excellence. Springer, 2015. 
HSU, D. W., SHEN, Y. C., YUAN, B. J., \& CHOU, C. J. Toward successful commercialization of university technology: Performance drivers of university technology transfer in Taiwan. Technological Forecasting and Social Change, v. 92, p. 25-39, 2015.

KERR, Clark. The uses of the university: with post scriptum 1972. Editions UFC, Universidade Federal do Ceará, 1982.

LI, Jun. World-class higher education and the emerging Chinese model of the university. Prospects, v. 42, n. 3, p. 319-339, 2012.

MARGINSON, Simon. Do rankings drive better performance? International Higher Education, n. 89, p. 6-8, 2017.

MONTESINOS, P., CAROT, J. M., MARTINEZ, J. M., \& MORA, F. Third mission ranking for world class universities: Beyond teaching and research. Higher Education in Europe, v. 33, n. 2-3, p. 259-271, 2008.

MOHRMAN, Kathryn. Global competition among research universities. In: How world-class universities affect global higher education. Brill Sense, 2014. p. 177-191.

NETWORK of Technological and Polytechnic Universities of Latin America and the Caribbean (RUTyP). [Online document]. Available at: $<$ http://www.rutyp.org $>$. Accessed on: 12 nov. 2019.

PEREZ-ESPARRELLS, Carmen; ORDUNA-MALEA, Enrique. Do the technical universities exhibit distinct behaviour in global university rankings? A Times Higher Education (THE) case study. Journal of Engineering and Technology Management, v. 48, p. 97-108, 2018.

PIIRAINEN, Kalle Artturi; ANDERSEN, Allan Dahl; ANDERSEN, Per Dannemand. Foresight and the third mission of universities: the case for innovation system foresight. Foresight, v. 18, n. 1, p. 24-40, 2016.

RIBEIRO-SORIANO, Domingo E.; BERBEGAL-MIRABENT, Jasmina. Disseminating scientific research: a double-edged sword? Knowledge Management Research \& Practice, v. 15 , n. 3, p. 380-390, 2017.

SALMI, Jamil. The challenge of establishing world class universities. The World Bank, 2009.

TROW, Martin. Reflections on the transition from elite to mass to universal access: Forms and phases of higher education in modern societies since WWII. In: International handbook of higher education. Springer, Dordrecht, 2007. p. 243-280. 